\author{
Saša Babič \\ Inštitut za slovensko narodopisje, ZRC SAZU, Ljubljana \\ DOI: $10.4312 /$ SSJLK.57.80-88
}

\title{
Stereotipna podoba ženske v slovenskih folklornih obrazcih
}

\begin{abstract}
Folklorni obrazci, kot so pregovori, uganke, šale pa tudi zagovori, ponujajo stereotipen - v etnolingvističnem pomenu - pogled na žensko in njen položaj v družbi. Relativno stalne jezikovne oblike namreč shranijo družbeno informacijo tako o vlogah kot o pogledu drugih na posameznico, ki lahko predstavlja splošno žensko, lahko pa posameznico z določeno lastnostjo. Iz teh kratkih folklornih oblik se tako deloma razkrije tudi položaj določenega spola v družbi, v našem primeru ženskega. Medtem ko pregovori pokažejo diahroni vidik posameznega spola, nam šaljiva vprašanja pokažejo sodobne družbene izzive, ki so vezani na spremembe vidikov.
\end{abstract}

folklorni obrazci, pregovor, uganka, humor, ženska

Short folklore forms, such as proverbs, riddles and jokes, as well as incantation, offer a stereotyped view - in the ethnolinguistic sense - of women and their role in society. For relatively stable language forms preserve social information about roles and the views of others on the individual female, who can represent woman in general or an individual with particular qualities. These short folklore forms can also reveal the position of a particular gender in society - in this instance the female. While proverbs show a diachronic aspect of a particular gender, joking questions show contemporary social challenges connected with changes in views.

short folklore forms, proverb, riddle, humour, woman

\section{Uvod $^{1}$}

Odnos do določene skupine s skupnimi značilnostmi ljudi se izraža tudi v folklornih oblikah, ki s svojo počasno spremenljivostjo hranijo določene vidike in kontekste dalj časa. S pomočjo branja kulture iz slovstvene folklore, upoštevajoč zgodovinski kontekst, se nam lahko pokažejo globlji vzorci družbenih vidikov. Čeprav se je družbeni položaj žensk v zadnjih sto letih v Sloveniji bistveno spremenil, predvsem izboljšal, je še vedno opaziti vpliv preteklih mišljenj - ta se verjetno prenašajo tudi z jezikovnimi oziroma folklornimi obrazci, ki po drugi strani ostajajo v družbi, dokler so pač aktualni.

V prispevku se bom posvetila družbenim vidikom ženske ter opozorila na stereotipe, prikazane v folklornih obrazcih, predvsem v pregovorih in ugankah (šaljivih vprašanjih). Te vidike bom interpretirala s pomočjo konceptov lingvistične antropologije in etnolingvistike, ki izpostavljata prav branje kulture skozi jezik.

\section{Lingvistična antropologija in etnolingvistika kot orodji za raziskovanje družbenega vidika posameznega elementa}

Lingvistična antropologija raziskuje kulturo skozi kulturni pomen besed: lingvistični pomen je določen s kulturnim kontekstom, v katerem se določen jezik pojavlja. Prav zato jezik in kultura pri

1 Prispevek je nastal v okviru raziskovalnega projekta Tradicionalne paremiološke enote v dialogu s sodobno rabo (ARRS J6-2579) in programa Etnološke in folkloristične raziskave kulturnih prostorov in praks (ARRS P6-0088). 
interpretaciji ne moreta biti ločena (Forrester 1996: 48). Ta pristop je tudi raziskovalni temeljni okvir "svetovnega nazora". Kot trdi Frawley (1992: 46), so jezik, kultura in misel ogledalo drug drugemu, prav zato je možno brati kulturo skozi jezik, ker jezikovne raznolikosti odsevajo kulturne raznolikosti, kar posledično lahko generira tudi raznolikosti v mišljenju. Podobno tudi po etnolingvističnih pojmovanjih jezik $v$ teku svojega obstoja sprejme vase kulturne smisle - izrazi predstav o svetu in o človeku se nahajajo v pomenih besed, v frazeologiji, včasih celo v slovnici. Jezik služi kot material kulture, hkrati pa se pojavlja kot metajezik kulture, ki se utrjuje v verbalnih formah smislov, motivov, tolmačenj, ocen in kognitivnih modelov sveta. Skupaj s slovstveno folkloro in kot del slovstvene folklore je jezik pojmovan kot eden od kulturnih kodov, ena od form izražanja kulturne tradicije ter eden od virov raziskovanja kulture in rekonstrukcije njegovih zgodnjih stanj. Povezava jezika s folklornimi in drugimi vrstami kulture je vzajemna (Tolstaja 2006: 20). Etnolingvistika raziskuje folkloro skozi jezikovni stereotip, kot posplošeno predstavo v jeziku, ki je dostopna skozi jezik in pripada kolektivnemu znanju o svetu (Bartminski 2005: 12-15). Folklora v takšni raziskavi nikakor ne predstavlja relikta preteklosti, temveč tudi sodobne rabe stalnih folklornih obrazcev. Etnolingvistika vidi sorodnost kulture in jezika kot podoben funkcijski znakovni sistem, pri čemer meja med jezikovno in kulturno semantiko ni ostra, ampak je odvisna od razumevanja semantike besede (tudi konotativnih komponent) (Tolstaja 2006: 9-12).

Aktivni govorec določenega jezika je del družbe, kar pomeni, da je del širših družbenih aktivnosti, ki so vpete $v$ določeno kulturo. Znotraj te kulture se ustvarjajo vzorci, tudi jezikovni, pri čemer njihovo rabo narekuje kontekst (Forrester 1996: 45). Jezikovni vzorci prek metafor izražajo koncepte, ti pa zopet kažejo na naše razumevanje zunanjega sveta (Lakoff, Johnson 1980: 3). Jezikovni koncepti so pri izražanju pomembni, saj v določenem kontekstu predstavljajo strukturo za razumevanje sporočila (Frawley 1992: 54). Čeprav Lakoff in Johnson s svojo tezo o konceptualni metafo$\mathrm{ri}^{2}$ kot univerzalnem mehanizmu $v$ sporazumevanju predpostavljata enako razumevanje metafor vseh aktivnih govorcev, hkrati pa izključujeta individualne odstope razumevanj, lahko o splošni sliki družbe $v$ jeziku predvidevamo iz družbeno sprejetih in splošno rabljenih folklornih obrazcev. Pri teh imamo $v$ mislih predvsem pregovore in dandanes prevladujoč tip ugank, tj. šaljiva vprašanja.

\section{Ženska v folklornih obrazcih}

Folklorni obrazci so relativne stalne povedne strukture. Ko preidejo družbeno cenzuro in jih govorci pripustijo $v$ jezik, $v$ njem navadno ostajajo dlje časa. S tem pa nosijo informacijo o preteklih časih $v$ širšem pomenu. $V$ prispevku se bom osredinila na opis ženske $v$ folklornih obrazcih, pri čemer bodo izpostavljeni pregovori kot kazalec preteklosti in šaljiva vprašanja kot sodobno upovedovanje določenih vidikov na ženski spol.

Ženska je bila $v$ 18. in 19. stoletju manj izobražena oziroma je formalno lahko dobila zgolj osnovno izobrazbo, ${ }^{3}$ nadaljnje šolanje pa je bilo privilegij moških. Žensko delo in njihova glavna družbena vloga je bila večinoma vezana na gospodinjska opravila ter negovanje in skrb za svojo ali drugo družino (kuhanje, čiščenje in pranje, vzgoja otrok itn.). Posredno s tem je bila vloga

2 O konceptualni metafori v slovenskem jeziku piše tudi Agnieszka Będkowska Kopczyk (2004).

3 Dekret Marije Terezije o obveznem šolanju otrok leta 1776 je želel zagotoviti osnovno pismenost prebivalstva; Šolska splošna naredba: vsi otroci od 6 . do 12. leta so imeli obvezno splošno šolsko obveznost ne glede na spol. 
ženske v družinski dinamiki in tudi ekonomiji precejšnja, kar je moč razbrati tudi v pregovorih, ki so izpričani vsaj v 19. stoletju ali pa že prej.

\section{Raba slovničnega spola za oznako ženske v slovenskem jeziku}

V okviru lingvistične antropologije ne gre zanemariti odnosa do spola že na ravni rabe slovničnega spola v slovenščini ob živih bitjih z jasno določenim spolom. Slovenski jezik namreč označujejo trije (slovnični) spoli: ženski, moški in srednji. Pripona za tvorbo poimenovanj živalskih mladičev oziroma naziv nedoraslega potomca (moškega ali ženskega) v slovenskem jeziku tvori srednji slovnični spol (tele, žrebe ipd.) (Slawski 2011: 174; Marko Snoj, v pogovoru, marec 2020) - torej za tisto, "za kar še ne vemo, katerega spola je in katerega bo postalo« (Erika Kržišnik, v pogovoru, september 2015) ali pač čigar spol je v tej fazi še nepomemben (Marko Snoj, v pogovoru, marec 2020). Enako tvorbo zaznamo v besedi, ki označuje mlado, nedoraslo ali neporočeno žensko, tj. dekle. Beseda dekle je ekspresivna in pogovorna (SSKJ). Pri rabi enakega oblikovnega vzorca za moški spol, tj. fanté, najdemo oznako ekspresivno, navadno z negativno konotacijo (SSKJ), tako za živali kot žaljivka za ljudi (npr. prase kot prašič, prašiček ali 'ničvreden, malovreden človek'). Navedeno kaže, da se slovnični srednji spol pri ljudeh splošneje uporablja za đoraščajočo mlado žensko' (SSKJ), tj. dekle, medtem ko pri moškem spolu zgolj z ekspresivno, slabšalno konotacijo, tj. fanté. Iz navedenega lahko sklepamo, da srednji spol označuje živa bitja, za katera (še) ne moremo določiti ne le naravnega, temveč pri ljudeh predvsem družbenega spola, kar pomeni nedoraslost, nejasnost, lahko tudi konceptualno neoprijemljivost in variantnost glede na družbene potrebe, s tem pa določeno spremenljivost, zaradi česar vsekakor dobi negativno konotacijo. Ženska je tako v odraščajoči dobi jezikovno označena kot neizoblikovana in s tem družbeno prilagodljiva ter lahko manj vredna, medtem ko je moški spol jezikovno gledano vedno določen, dokončen, moški. Zdi se, da je - gledano diahrono - ženska jezikovno identiteto lahko prevzela šele, ko ji je družba dodelila družbeno identiteto ženskega spola prek ritualov (npr. s poroko ali pa s sprejemom funkcije gospodinje neporočenemu ali ovdovelemu bližnjemu sorodniku oziroma pomočnice-varuške svojim nečakom, t. i. teta). ${ }^{4}$

\section{Ženska v pregovorih}

Pregovori za svoje opise v večini uporabljajo svet odraslih in s tem tudi poimenovanje moških in žensk (mlajše generacije so poimenovane enotno - otroci). Zato je ženski spol v slovenskih pregovorih načeloma poimenovan šele s poimenovanjem odrasle kategorije in se začne $z$ ritualnimi poimenovanji ob dodelitvi družbenih vlog in spola (npr. nevesta). V gradivu arhiva ISN ZRC SAZU je bil pregovor z elementom dekle le en (v nadaljevanju). Ko je bil ženski dodeljen tudi družbeni ženski spol in s tem njena vloga v družbi, se je odnos do spola kot takega odtisnil v relativno stalnih

4 V Albaniji še vedno obstajajo ženske, t. i. virdžine, ki so ob smrti očeta ali kot najmlajše hčere v družini brez sinov zaprisegle celibat ter prevzele moško vlogo v družini - začele so nositi moška oblačila in se obnašati kot moški. Prevzele so družbeno vlogo moškega, čeprav so bile po naravnem spolu ženske. Zaradi družbene vloge moškega so jih tudi nazivali kot moške. Navedeno je dokaz, da je raba spola za človeka v jeziku močno vezana na družbeni spol. Ob tem se postavlja vprašanje rabe moškega spola za ženske v več slovenskih gorenjskih narečjih, v narečjih v delih Goričkega, Porabja, Haloz, pa tudi v južnopoljskih narečjih - ali gre tudi to rabo povezovati z ostanki preteklih družbenih vlog in položajev? 
besednih zvezah (pregovori, žaljivke ipd.) ali besedilih (pravljice, povedke ipd.). Pregovori so ujeli družbeni stereotip, ki se je izoblikoval skozi daljši čas, in s tem tudi zaznave in pričakovanja glede na družbene kategorije.

Eden redkih pregovorov z besedo dekle (Dekle je angel, žena je dar božji, a baba je hudič) pokaže sliko, da je dekle še »neizoblikovana« in neizkušena, predvidoma neproblematična za okolico. Žena po družbenem stereotipu označuje žensko, ki dobro poskrbi za dom in družino, baba pa nosi negativno konotacijo in označuje žensko, ki naj bi bila zlobna, kar je izpričano tudi v drugih slovenskih pregovorih. Pregovor uporabi kar tri poimenovanja ženskega spola, ki so kategorizirana glede na starost, s tem pa kaže tudi različne vidike na samo starost in hkrati na izkušenost (bolj zaželena so bila dekleta, kot še neizkušena in s tem še primerna za »vzgojo«). Sicer nepoimenovano, pa vendar jasno izraženo, se lahko nevesta izkaže za drugačno od pričakovanega po zagotovitvi družbenega položaja žene - namesto upogljiva je ženska zahtevna: Pred zakonom golobica, po zakonu orlica. Pregovor uporabi metaforično primero s stereotipom o pticah in njihovem obnašanju - golobica naj bi bila mila, nežna, medtem ko je orlica odločna in napadalna.

Družbena slika obetajočega se pomena neveste za družino je razvidna v pregovoru: Nevesta prinese $k$ hiši doto pa zibel. Nevesta je prinesla v novo družino materialne dobrine, s katerimi naj bi se povrnil vložek, ki ga bo v prihodnosti morala dati nova družina za njeno življenje. Zibel pomeni naraščaj, kar zagotavlja nadaljevanje družine in nove nosilce družinskega imena.

Ko je ženska prevzela vlogo žene, je načeloma morala sprejeti tudi obvezno skrb za moža in družino in s tem pričakovan nabor gospodinjskih znanj; to je razvidno iz pregovorov: Tista, ki hlače zaflikat ne zna, naj si ne išče moža; Ko ima žena perilo v čebru in kruh v peči, ni jej treba veliko reči; Je pridna žena, je stava dobljena. ${ }^{5}$ Izpostavlja se tudi vidik, da brez znanja in marljivosti ženska (pa tudi moški) ni nič vredna, v novo družino pa je človek sprejet le, če ima vrednost in znanja, ki so v prid širši skupnosti.

Vrednost ženske je bila določena tudi glede na estetski kriterij vrednotenja ženskega izgleda, pri čemer višina, suha postava, ponosna drža in naličenost niso bili zaželeni: Bel konj in velika ženska sta dve nesreči pri hiši; Kadar je ženska trlja, je nora; Lišpana deklica, umazana ženica. Zaželena ženska je bila vizualno (pa tudi po drugih značilnostih) neopazna, neizstopajoča.

Pregovori ženskam pripisujejo večjo verbalno aktivnost, kar pogosto postavljajo v kontekst širšega prostora, npr. trg: Dve ženski - trg, tri - semenj; Dve babi pa sraka - cel sejem. ${ }^{6}$ Večja verbalna aktivnost žensk je stopnjevana v obrekovanje, celo nekontrolirano podajanje vsega vedenja: Ženska zamolči, kar v glavi nič ni; Samo bedaki prosijo ženske naj o tem, o čemer so govorili, molče. ${ }^{7}$ Klepetavost je bila tako stereotipna in vsesplošno ženskam pripisana lastnost, da jo je družba povezala z regljanjem žab pred dežjem in v vražo, da če ženske klepetajo (regljajo), bo dež (po analogiji iz živalskega sveta, ko žabe pred dežjem intenzivneje regljajo). Vraža je še vedno v rabi, največkrat v humorne namene. Za ženske naj bi bil značilen tudi predrzen in nesramen govor, kar je pogost likovni folklorni motiv (hudič brusi babi jezik): Bog je ženski iztrgal jezik ter ga usadil in

5 Delo žensk je prikazano tudi v pravih ugankah, npr.: Suh pod vodo. Kaj je to? - Žena pod škafom.

6 Tudi prave uganke upodabljajo ta stereotip: Kateri jezik se ne giblje in ne govori? - Jezik pri ženskih čižmah [čevljih].

7 Prava uganka Kdo ni mož beseda? - Ženska uporablja stereotip, da ženska ne more držati obljube, uganka pa je zgrajena tudi na pomenskem nasprotju moški : ženska. 
uzrasel je hren. Z večjo verbalno aktivnostjo in izraznostjo pa seveda pregovori ženskam pripisujejo tudi prepirljivost: Dve ženski v kuhinji je huje ko sodnji dan; Skoraj ni prepira, ki od žene ne izvira.

Družbena vloga žensk je imela glavni poudarek na vlogah ženske $v$ družini. Njena odgovornost je segala vse od nege družinskih članov, vzgoje otrok, zagotavljanja in pripravljanja obrokov do urejanja doma. Zato je bila znotraj družinskega kroga $v$ večini primerov nepogrešljiv del družine, kar je razvidno iz pregovorov: Žena derži hiši tri vogale, mož le enega; Žena drži hiši tri ogle in še četrtega možu pomaga; Hiša ne stoji na zemlji, nego na ženi. Vpliv žene na moža oziroma ženske $v$ družini je razviden tudi iz pregovora, ki izpostavlja, da ima ženska glavno besedo v družini: Mož je glava, žena vrat, ki obrača glavo, kamor hoče; Mož pleše, kakor mu žena žvižga. Vloga ženske v življenju moškega pa je izražena v pregovoru, ki izkazuje odvisnost moškega od ženske: Žena je možu dom; Ko mati umerje, oče cerkne.

Vpliv žene in mame znotraj družine je viden tudi v pregovorih, ki izpostavljajo meddružinska razmerja oziroma vplive:

- vpliv matere na hčer, pri čemer naj bi mati hčer izoblikovala po svoji podobi: Če je mati spaka, rada je hči tudi taka; Kakršna matka, taka Katka.

- velika vloga materinstva: Mama je ena sama; Mati ne pozna slabih otrok.

- če ženska (očitno) prevzame nadzor v družini, se slabo piše možu, saj je v slabšem položaju: Gorje možu, ki mu je žena slekla hlače; Kder žena klobuk nosi, mož slabo kosi; Kjer žena hlače nosi, si mož kruha prosi.

- odnos do ženske pa se je razlikoval tudi v širši družini. Pregovor izpostavlja, da mož želi zdravo, tj. funkcionalno ženo, ki bo sposobna poskrbeti za dom, medtem ko brat želi le njen denar: Mož ljubi zdravo ženo, brat bogato sestro.

Danes so pregovori pogosto interpretirani kot podcenjujoči do ženskega intelekta. Kot argument za to trditev najpogosteje navajajo pregovor: Dolgi lasje - kratka pamet. Ravno pri tem pregovoru se pokaže pomen poznavanja pomenskih nians in zgodovinskega ozadja. V govoru 19. stoletja se namreč besedi pameten in pamet ne nanašata na inteligenčno sposobnost, ampak sta vezani tudi na izobraženost, kar je še danes izpričano v dialektnih govorih starejših prebivalcev, ko nekoga označijo za "pametnega, saj je šel študirat«. Pregovor Dolgi lasje - kratka pamet zato v prvi vrsti - gledano diahrono - izpostavlja neizobraženost žensk. Hkrati je ravno pri tem pregovoru vidna tudi spremenljivost pomenskosti folklornih obrazcev: ob novih pomenskih odtenkih se kažejo tudi spremembe razumevanja folklornega obrazca. $V$ današnjem pomenu besede pameten je govora predvsem o brihtnosti, premetenosti, iznajdljivosti, kar so bile pogosto lastnosti, ki so ženske privedle do karakterizacije kot hudičeve - največkrat v povezavi z govorom, kar lahko pomeni tudi, da so ženske drznejše: Kamor si hudič ne upa, pošlje babo; Kateri vzame ženo radi blaga, nameri se na vraga. Vsekakor je neizobraženost vplivala na slabše ravnanje z denarjem in posledično na revščino: Mož mora imeti denar v rokah; Kjer je baba gospodar, je volk mesar.

$\checkmark$ preteklih stoletjih so bile ženske $v$ veliki meri odvisne od moških. Kolikor je načeloma vsaka družina potrebovala žensko za nego in naraščaj, je ravno nadvlada patriarhata in superiornost moških (tudi izobrazbeno) postavila ženske $v$ nesamostojen in odvisen položaj. To se pokaže tudi $\checkmark$ pregovorih, ki izpostavljajo nesamostojnost žensk in hkrati obvezno ponižnost: Če ima žena moža, ki ve, kaj dela in zakaj to dela, naj trdo molči in ve, da ji bo tako dobro; Mož en sam vogel 
podpira, če tistega spusti, vsi štiri padejo. Superiornost moškega nad žensko je izkazana tudi v podpiranju nasilja moških do žensk: Ljubi svojo ženo kot svojo dušo, stresaj jo kot hruško in stepaj jo kot svoj kožuh. Družbena večvrednost moških je prikazana celo z analogijo na les, in sicer ženska je mehka in hitro uničljiva, je kakor smreka, moški je trd(en) in bolj kvaliteten, je kot hrast: Smreka ni hrast (ženska ni moški).

Starejše ženske so v pregovorih največkrat poimenovane baba. Te niso bile zaželene, saj so veljale za problematične, zlobne: Stari babi štrik (vrv) za vrat, mladi Micki prstan zlat. Nezaželenost starejših žensk vključuje tudi tašče in stereotip, da se jih je treba znebiti, če želi moški dobro vladati družini: Kedar se oženiš, bodi ti prva skrb, da spodiš taščo iz hiše.

Pregled pregovorov daje očitno sliko stereotipov, ki se vlečejo še dandanes (in bodo očitni v obravnavi stereotipov v šaljivih vprašanjih): ženske izpostavljajo kot klepetave, obrekljive, prepirljive, manj izobražene, njihova naloga bi morala biti le skrb za družino in dom, medtem ko naj bi prepustile pomembna odločanja moškemu. Starejše ženske, sploh tašče, so zlobne in nezaželene. Izraz žena je edini od poimenovanj za ženski spol, ki v pregovorih nosi pozitivno konotacijo. Hkrati pa pregovori pokažejo ženske kot članice družbe, ki delujejo iz ozadja in neopazno odločajo, na njih stoji dom in funkcija vzgoje bodočih rodov.

\section{Šaljiva vprašanja}

Vpogled na ženski spol v sodobni slovstveni folklori lahko dobimo v šaljivih vprašanjih. Šaljiva vprašanja uvrščamo med uganke kot samostojni tip in v sodobnem času tudi prevladujoč: ohranjajo dialoško strukturo uganke vprašanje - odgovor, pri čemer je odgovor presenetljiv in temelji na humorju. Poznavanje odgovora ni zaželeno, saj nepoznavanje presenetljivega odgovora nosi poanto humornega preobrata in s tem humorno funkcijo, s katero se šaljiva vprašanja uvrščajo tudi med humorne žanre, tj. vice. Obsegajo širok spekter tem iz vsakdanjega življenja, s tem pa vključujejo tudi družbene vidike in stereotipe na posamezne kategorije, kot so funkcije spolov, karakteristike ras, inteligentnost posameznikov itn. Šaljiva vprašanja se zastavljajo v družbi vseh emocionalnih in intelektualnih nivojev.

Pogost način vzbujanja humorja v teh ugankah so nepričakovane primerjave: te so navadno sprva nelogične in izven konteksta, vendar potem presenetljiv odgovor poda skupno/povezovalno točko med primerjanim in primerjalnim. V teh povezavah se kaže človekova domišljija pri vzbujanju humorja; izrazijo se predsodki in stereotipi - kot "slike v naših glavah « (Lippmann 1922) -, ki so sicer zakriti pod krinko naprednih družbenih nazorov. Stereotipi v sodobnih šaljivih vprašanjih temeljijo na posplošenih podobah.

Šaljiva vprašanja na temo nasprotnega spola (ne glede na to, ali je ženski ali moški spol) so vsebinsko šovinistična: izražen je večvrednostni vidik lastnega spola in sovražen, podcenjujoč, zaničevalen odnos do nasprotnega spola. ${ }^{8}$ Ta šaljiva vprašanja se nanašajo predvsem na različne sposobnosti spolov, na fizične in nekatere karakterne lastnosti. Izpostavljajo predvsem (ne)sposobnosti in lastnosti, ki naj bi predstavljale stereotip o določenem spolu.

8 Čeprav naj bi obveljalo splošno prepričanje, da moški večkrat posežejo po takih vicih (Dundes 1987: 82), pa gradivo tega ne potrjuje. Pregledani slovenski forumi in internetne strani so dale bistveno več različnih enot šaljivih vprašanj na temo moških kot na temo žensk, kar nakazuje na povečano žensko kritičnost, nestrpnost, zaničujoč odnos do moških. 
Šaljiva vprašanja na temo žensk obsegajo vsa vprašanja, ki žensko poimenujejo kot blondinko, ženo, žensko in taščo. Pri vseh gre za predstavnice ženskega spola, ki so kategorizirane zgolj po določenih lastnostih. $V$ teh šalah so predmet humorja vedno odrasle ženske: mlajše odrasle ženske (blondinke) ali starejše ženske (tašča). Vse te karakteristike pokažejo različne stereotipe, vezane na ženske: blondinke so mlade in privlačne, a neumne in nepotešljive; poslanstvo žena je gospodinjstvo in skrb za moškega, njihova podoba ni v ospredju opisa; ženske stereotipno ne nehajo z govorjenjem; tašče so starejše ženske, pri katerih je izpostavljena zloba in odvečnost, pogosto je omenjena tudi proteza kot simbol starosti. Ne glede na specifiko posamezne ženske karakteristike pa vsa šaljiva vprašanja reproducirajo stereotipe, ki se - kot smo pokazali pri pregovorih - pojavljajo že v prejšnjih stoletjih.

Ženska je $v$ šaljivih vprašanjih primerjana $z$ vsakodnevnimi predmeti ali prostori, vremenskimi pojavi, živalmi, boleznimi, domišljijskimi bitji, z nasprotnim spolom ali z istim spolom, vendar v drugem družbenem položaju:

Kaj imata skupnega tašča in krompir? - Oba sodita v zemljo.

Kakšna je razlika med žensko in tumorjem? - Za tumor ni nujno, da je smrtno nevaren.

Kakšna je razlika med ženo in psom? - Ko ženo spustiš v hišo, še naprej laja, pes pa utihne.

Edina naloga in poslanstvo ženske naj bi bila skrb za dom in naslednje rodove:

Zakaj je na svetu več žensk kot moških? - Ker je po svetu več za čistit kot za mislit!

Zakaj imajo ženske manjša stopala od moških? - Pač ena "evolucijskih zadevic“, ki jim omogoča, da lahko stojijo bliže pomivalnemu koritu.

Zakaj je uporaben ženski spolni organ? - Za nadaljevanje generacij žensk za čistit po hiši.

Ta šaljiva vprašanja obravnavajo žensko kot predmet. Obstoj ženske opravičuje zgolj določena uporabnost ali dejavnost, ki jo opravlja. Popredmetenje ženske je hkrati konceptualno zniževanje vrednosti: ženska ni več oseba, le še uporaben predmet.

Inteligenčne sposobnosti ženske naj bi bile nižje, razumevanje pomanjkljivo in njihove orientacijske sposobnosti slabše:

Zakaj imajo ženske 469 kosti več kot moški? - Ker jim možgani delujejo še mehansko!

Kako blondinka dobi marmelado? - Tako da olupi krof.

Zakaj ženske v povprečju živijo 8 let dlje? - Ker jim je bog povrnil čas, ki so ga porabile za parkiranje avta.

V šaljivih vprašanjih je stereotip pripeljan tako daleč, da mlada ženska sploh naj ne bi imela možganov oziroma metaforično nobenega znanja:

Kaj je to, če se blondinka ustreli v glavo? - Strel v prazno.

Zakaj blondinka tako hitro pokadi cigareto? - Ker ima vakuum v glavi.

Zakaj snežak nima votle glave? - Ker ni ženska.

Tudi stereotip povečane verbalne aktivnosti je še vedno izpostavljen:

Kakšna je razlika med telefonom in ženo? - $V$ telefon vržeš kovanec in lahko govoriš, ženi pa daš celo plačo, pa moraš biti še vedno tiho. 
Ženska je bitje, ki naj bi v moškem svetu veljala za zlobno in uničujoč faktor za moškega: Zakaj imajo ženske menstruacijo? - Ker cel mesec pijejo kri moškim, zato mora nekje udariti ven! Kakšna je razlika med žensko in tumorjem? - Za tumor ni nujno, da je smrtno nevaren.

Šaljivo vprašanje, ki po strukturi oponaša pravo uganko z uvodno formulo in tudi samo strukturo vprašanja, navaja metaforične lastnosti odgovora kot opis njegove dejavnosti. Odgovor razkrije, da gre za šaljivo vprašanje, poanta pa je prav v nenavadni navezavi odgovora na opis:

Kaj je to? Ponoči plava, podnevi laja. - Proteza od tašče.

Navedena šaljiva vprašanja so le del nabora in so v prispevku izpostavljena predvsem kot prikaz, kako stereotipi ostajajo $v$ družbi in se prenašajo tudi iz konzervativnejših žanrov v sodobne oblike slovstvene folklore. Šaljiva vprašanja o ženskah so pogosto seksistična, nanašajo se na nepotešljivo slo in omejeno inteligenčno sposobnost ali pa poudarjajo, da je edina funkcija ženske gospodinjstvo. Šovinizem in žaljivost se z anonimnostjo na spletu (npr. na forumih) lahko le še stopnjujeta.

\section{Sklep}

Vpogled v stereotipe, ki so uporabljeni v folklornih obrazcih, nam omogoča vpogled v družbo kot tudi $v$ očitno stabilnost teh stereotipov. $V$ prispevku so bili prikazani pregovori in šaljiva vprašanja na temo ženske. $V$ pregovorih so ženske prikazane neobvladljivo klepetave, prepirljive, njihova naloga naj bi bila skrb za dom in družino, zaželeno je, da so neopazne (tako fizično kot tudi vedenjsko). Mlade ženske so naivne in jih je mogoče še spreminjati po željah, medtem ko so stare ženske označene kot babe (tudi tašče), tj. zoprne, zlobne, in so predvsem nezaželene. Enake stereotipe najdemo tudi v sodobnih šaljivih vprašanjih na temo žensk. V teh so mlade ženske, običajno poimenovane blondinke, prikazane kot naivne, celo neumne, tašče pa enako kot v pregovorih: zoprne, zlobne in nezaželene. Šaljiva vprašanja enako kot pregovori izpostavljajo, da je namen žensk gospodinjstvo in skrb za družino oziroma njenega moškega, hkrati pa jih šaljiva vprašanja degradirajo na raven uporabnega predmeta.

Razlika med pregovori in šaljivimi vprašanji se pojavi pri pojmovanju inteligenčnih sposobnosti ženske: pregovori ob diahroni interpretaciji bolj izpostavljajo nezmožnost določenih nalog zaradi neizobraženosti žensk in ne manjše inteligenčne sposobnosti, medtem ko šaljiva vprašanja označujejo žensko za inteligenčno manj sposobno bitje (tako $v$ šaljivih vprašanjih o blondinkah kot o ženskah). Pri šaljivih vprašanjih se pojavi tudi tematiziranje nepotešljivosti žensk, česar v pregovorih ne najdemo (tema seksualnosti se pojavlja tudi pri šaljivih vprašanjih o moških). Porast te teme je očiten od leta 1990 dalje, ko se je začelo o tem širše in bolj sproščeno govoriti in ko je družba začela sproščati frustracije ob spremembah družbenih razmerij med spoloma $v$ humorju na račun nasprotnega spola (Davies 2011). Pri humorju, ki kroži znotraj skupine, tudi humorju, ki je vezan na nasprotni spol, lahko govorimo o identitetah: funkcija takšnih šaljivih vprašanj je ublažiti neke vrste ontološki strah pred neznanim in nenadzorovanim (Vučetić 2004). V splošnem lahko trdimo, da so šale uporabljene za blaženje izgube občutka pripadnosti in identitete (Vučetič 2004) z vzpostavljanjem kategorije »drugega« ( $v$ tem primeru nasprotnega spola). Na ta način se določajo in vedno 
znova postavljajo meje družbeno diferenciranih skupin in ločevanja »mi« od »oni (Apte 1985: 55). $\mathrm{V}$ ta namen so uporabljeni splošni družbeni stereotipi, ki jih lahko razumemo tudi kot »družbene kazalce (Duara 1996: 165).

Čeprav je družba vnesla nekaj manjših sprememb v stereotipe o spolih, se niso spremenile glavne stereotipne podobe o spolu (ne glede na žanr), nekateri stereotipi so še okrepljeni (klepetavost in neumnost žensk). Na teh primerih lahko vidimo stabilnost in zasidranost stereotipov v družbo, hkrati pa stabilnost folklornih obrazcev kot nosilcev teh stereotipov (pregovori kot relikt večstoletne komunikacije, šaljiva vprašanja kot dediščina več rodov).

\section{Viri in literatura}

APTE, Mahadev L., 1985: Humor and Laughter: An Anthropological Approach. Ithaca, New York: Cornell University Press. Arhiv pregovorov Inštituta za slovensko narodopisje ZRC SAZU.

Arhiv ugank Inštituta za slovensko narodopisje ZRC SAZU.

BABIČ, Saša, 2011: Lingvistična antropologija in etnolingvistika. Studia Mythologica Slavica 14. 196-180.

BABIČ, Saša, 2018: Stereotipi in predsodki o ženskah in moških v šaljivih vprašanjih. Renata Jambrešić Kirin (ur.): Humor u svakodnevnoj komunikaciji (Biblioteka Nova etnografija). Zagreb: Institut za etnologiju i folkloristiku. 81-95.

BARTMIŃSKI, Jerzy, 2005: Jazykovoj obraz mira: očerki po etnolingvistike. Moskva: Indrik.

BĘDKOWSKA KOPCZYK, Agnieszka, 2004: Jezikovna podoba negativnih čustev. Ljubljana: Beletrina.

BERGER, Peter L., LUCKMANN, Thomas, 1996: The Social Construction of Reality. A Treatise in the Sociology of Knowledge. London: Penguin books.

CONNOLLY, William E., 2002: Identity/difference: Democratic Negotiations od Political Paradox. Minneapolis: University of Minnesota Press.

DAVIES, Christie, 2011: Jokes and their Targets. Bloomington, Indiana: Indiana University Press.

DUARA, Prasenjut, 1996: Historicizing National Identity, or Who Imagines What and When. Geoff Eley, Ronald Grigor Suny (ur.): Becoming National. Oxford: Oxford University Press. 151-177.

DUNDES, Alan, 1987: Cracking jokes: studies of sick humour cycles \& stereotypes. Berkeley: Ten Speed Press.

DURANTI, Alessandro, 1997: Linguistic Anthropology. Cambrige textbooks in Linguistics. Velika Britanija: Cambrige University Press.

KRŽIŠNIK, Erika, 2005: Frazeologija v luči kulture. Marko Stabej (ur.): Večkulturnost v slovenskem jeziku, literaturi in kulturi. 41. SSJLK. Ljubljana: Oddelek za slovenistiko. 67-81.

LIPPMANN, Walter, 1922: Public Opinion. New York: Harcourt, Brace \& Co.

MACIUSZEK, Józef, POLAK, Mateusz, ŚWIĄTKOWSKA, Natalia, 2019: Gramatical Gender Influences. Semantic Categorisation and Implicit Cognition in Polish. Frontiers in Psychology: https://www.frontiersin.org/articles/10.3389/ fpsyg.2019.02208/full (dostop marec 2020)

Slovar slovenskega knjižnega jezika [= SSKJ]. www.fran.si (dostop marec 2020)

SŁAWSKI, Franciszek, 2011: Słowotwórstwo, slownictwoi etymologia Słoowiańska. Krakow: Polska Akademia umijetnošci. TOLSTAJA, Svetlana M., 2006: Postulaty moskovskoj etnolingvistiki. Etnolingwistyka 18.

VUČETIĆ, Srđjan, 2004: Identity is a Joking Matter: Intergroup Humor in Bosnia. Spaces of Identity IV/1. 7-34. 